\title{
In the footsteps of Michel Allioni: Liverworts and hornworts from the surroundings of Gualaquiza (Ecuador)
}

\author{
S. Robbert Gradstein \& Álvaro J. Pérez
}

\begin{abstract}
GRADSTEIN, S.R. \& Á.J. PÉREZ (2021). In the footsteps of Michel Allioni: Liverworts and hornworts from the surroundings of Gualaquiza (Ecuador). Candollea 76: 41-54. In English, English and Spanish abstracts. DOI: http://dx.doi.org/10.15553/c2021v761a3

The liverwort and hornwort flora of Ecuador is still very incompletely known. We report three species new to Ecuador (Lejeunea rionegrensis Steph., Notothylas javanica (Sande Lac.) Gottsche, Riccia vitalii Jov.-Ast) and 38 new to the province of Morona Santiago based on our fieldwork in the surroundings of Gualaquiza, Morona Santiago, in 2019. The bryophyte flora of this area was explored in the early $20^{\text {th }}$ century by the Italian missionary and naturalist Michel Allioni. A brief eulogy of the life and work of Michel Allioni is presented together with a revision of the species described by Stephani based on Allioni's Ecuadorian collections. Almost all of them are synonyms. Sixteen new synonyms and seven new lectotypifications are proposed.
\end{abstract}

\section{Resumen}

GRADSTEIN, S.R. \& Á.J. PÉREZ (2021). Siguiendo los pasos de Michel Allioni: hepáticas y antocerotes de los alrededores de Gualaquiza (Ecuador). Candollea 76: 41-54. En inglés, resúmenes en inglés y español. DOI: http://dx.doi.org/10.15553/c2021v761a3

Las hepáticas y antocerotes de la flora del Ecuador aún son probremente conocidas. Con base en nuestros trabajos de campo en el 2019 en los alrededores de Gualaquiza (Morona Santiago), Ecuador, reportamos tres nuevos registros para el pais (Lejeunea rionegrensis Steph., Notothylas javanica (Sande Lac.) Gottsche, Riccia vitalii Jov.-Ast) y 38 nuevos registros para la provincia de Morona Santiago. Las briófitas de Gualaquiza fueron estudiados por el misionero Salesiano y naturalista Italiano Michel Allioni. Una remembranza de su vida y trabajos es presentada en este estudio, conjutamente con una revisión de las especies descritas por Stephani con base del material Ecuatoriano recolectado por Allioni. De estas últimas, casi todas son sinónimos. Dieciseis nuevos sinónimos son propuestos y se efectuan siete nuevas lectotipificaciones.

\section{Keywords}

Anthocerotophyta - Marchantiophyta - Ecuador - Floristics - Michel Allioni - Morona Santiago - Taxonomy

Addresses of the authors:

SRG: Department of Systematics, Biodiversity and Evolution of Plants, Albrecht von Haller Institute, University of Göttingen, 37073 Göttingen, Germany and Muséum national d'Histoire naturelle, Institut de Systématique, Évolution, Biodiversité (UMR 7205), 75005 Paris, France. E-mail: sgradst@gwdg.de AJP: Herbario QCA, Escuela de Ciencias Biológicas, Pontificia Universidad Católica del Ecuador, Apartado 17-01-2184, Quito, Ecuador. 


\section{Introduction}

The liverwort and hornwort flora of Ecuador has been much inventoried since the $19^{\text {th }}$ century, yet is still very incompletely known (LEón-YÁnez et al., 2006; SCHÄFER-VERwimp et al., 2013; Gradstein \& Benitez, 2017). Rather well-explored areas include the province of Pichincha, the Galápagos Islands, the upper Pastaza river valley and readily accessible sites in Parque National Podocarpus and adjacent areas in the south of Ecuador. Other parts of the country are underexplored (Gradstein, in press).

The province of Morona Santiago, located in the southeast of country, counts among the areas that have been poorly explored. Even though including a large part of Amazonian lowland territory and Andean cordillera, only 140 species of liverworts and 4 hornworts have been recorded from this province or about three times less than are known from the adjacent province of Zamora Chinchipe (LEón-YÁnez et al., 2006; Gradstein, in press). A remarkable recent addition to the flora of Morona Santiago was the robust dendroid liverwort Riccardia verticillata Gradst. \& Reeb from Reserva E1 Quimi in the Cordillera del Cóndor (Gradstein et al., 2019).

During the fall of 2019, the authors of this paper had the opportunity to collect liverworts and hornworts in the surroundings of Gualaquiza, a town in the south of Morona Santiago (canton Gualaquiza) at c. $850 \mathrm{~m}$ elevation, $3^{\circ} 24^{\prime} 13^{\prime \prime S}$, 78 34'54"W (Fig. 1). Surprisingly, our collections yielded numerous new species records for the province. The area of Gualaquiza is characterized by a humid tropical climate with high rainfall. The natural vegetation is dominated by evergreen tropical forests with abundance of palms (Iriartea deltoidea Ruiz \& Pav., Mauritia flexuosa L.f., Wettinia maynensis Spruce) as well as Lauraceae, Melastomataceae, Moraceae and Annonaceae. Bryophytes abound as epiphytes on trunks and branches, on soil and on living leaves. Currently, the natural vegetation of Gualaquiza is threatened by mining, livestock and selective extraction of fine woods (Roy et al., 2018; Mazabanda et al., 2020; PÉrez et al., 2020). However, forest remnants protected by private and state initiatives still remain in the area and are in need of study.

The bryophyte flora of the surroundings of Gualaquiza has been inventoried in the early $20^{\text {th }}$ century by the Salesian missionary Michel Allioni. Many new species and the new genus Allioniella Broth. (= Alloniellopsis Ochyra) have been described based on his collections (Brotherus, 1911, 1920; StePhANi, 1898-1924). Virtually no bryophyte collecting has been done in the area since Allioni's explorations and very little is known about this collector. A brief eulogy of Allioni's (short) life and work is therefore given here.

Michel ("Miguel") Allioni (1880-1912) was an Italian naturalist and missionary of the Salesian priests of Don Bosco who lived and worked during about three years in Gualaquiza, Ecuador (Prov. Morona Santiago), as head of the local Salesian



Fig. 1. - Map of the study area in southern Ecuador.

mission. Allioni had studied natural sciences, especially botany, at the University of Torino and arrived in Gualaquiza on 28 January 1909 (Allioni, 1909). The mission of Gualaquiza, established in March 1894, was the first Salesian mission in the Ecuadorian Amazon and included the vallies of the Gualaquiza and Bomboiza rivers in the south of Morona Santiago (GARcía, 1999). During his stay in Ecuador, Allioni did extensive ethnographic and bryological work. His ethnographic studies resulted in a detailed account of the life of the indigenous people of the Gualaquiza region, "La Vida del Pueblo Shuar". This book, which was published posthumously in 1978 and again in 1993 (Allioni, 1978, 1993), remains an important source of information on the Shuar indigenous people of Ecuador (BotTasso, 1993). Allioni's stay in Ecuador did not last very long; tragically, he died of yellow fever on 23 May 1912 during a brief stay in Guayaquil (Creamer, 2011). Some sources (e.g., Steere, 1948; RENNER, 1993) erroneously cited 1911 as the year of Allioni's death, which was probably a misrendering of Brotherus's brief text on Allioni (Brotherus, 1920: 1).

In the framework of his bryological explorations, Michel Allioni made hundreds of collections, mostly in the surroundings of Gualaquiza and Bomboiza but also in neighbouring areas; for a listing of Allioni's collecting localities see Appendix 2, and Brotherus (1920) and Steere (1948). Although being mostly from the province of Morona Santiago, Allioni's specimens are frequently cited as having being collected in the province of Azuay. The reason for this is that Morona Santiago was long part of the province of Azuay (together with the provinces of Napo and Pastaza), having been created as a separate province 


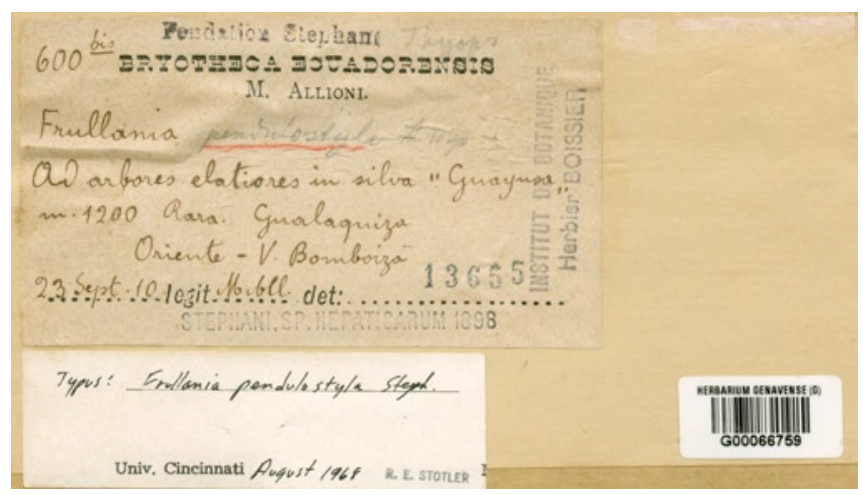

Fig. 2. - Label of holotype of Frullania pendulostyla Steph. at G.

only in 1953. Allioni's labels therefore frequently mention Azuay as province of origin of the specimen, instead of Morona Santiago. The only collections made by Allioni in Azuay, as currently defined, are from Chunchi and Cuenca, gathered in January 1909 while travelling from Guayaquil to Gualaquiza, and from the páramo of Matanga near the provincial border with Morona Santiago, visited by Allioni in October 1909 and again in November 1910.

Allioni's bryophytes include hundreds of collections. A notable feature of his specimens are the detailed labels, providing information (in Latin) on location, habitat, substrate, elevation and date of collecting (Fig. 2,3). As mentioned by Bottasso (1993: 23), Allioni's approach stood out by its "exactitud, minuciosidad, gusto por la clasificación, descripciones sintéticas, curiosidad insaciable". In spite of his dedication to the collecting of bryophytes, Allioni's contribution to bryology has been limited to gathering specimens. His early death at the age of 32 may well have prevented him to develop a career as a bryologist.

Allioni's moss collections were worked up by Victor F. Brotherus (1849-1929) in Finland, who published two papers on these materials, an annotated species list (BROTHERUs, 1920) and the description of a new genus, Allioniella (Sematophyllaceae). The latter genus - based on a specimen gathered by Allioni along the Río Bomboiza (Brotherus, 1911) - is still accepted as a good taxon but the name is illegitimate, having been earlier used for a genus of Nyctaginaceae, Allioniella Rydberg 1902, dedicated to the Italian botanist Carlo Allioni. As a consequence, the name Allioniella Broth. has been replaced by Allioniellopsis (Ochyra, 1982). Allioni's mosses counted 160 species including 36 species new to science, about half of which are still accepted (CHurchill et al., 2000). The specimens are kept in $\mathrm{H}$ and correspondence between Allioni and Brotherus is preserved in the Brotherus archives in the University of Helsinki Library (Koponen \& Piıppo, 2002).

While Allioni's moss collections have been well documented, less is known about his collections of liverworts and hornworts. The latter were worked up by Franz Stephani (1842-1927) in Leipzig, who probably received the material as a gift for

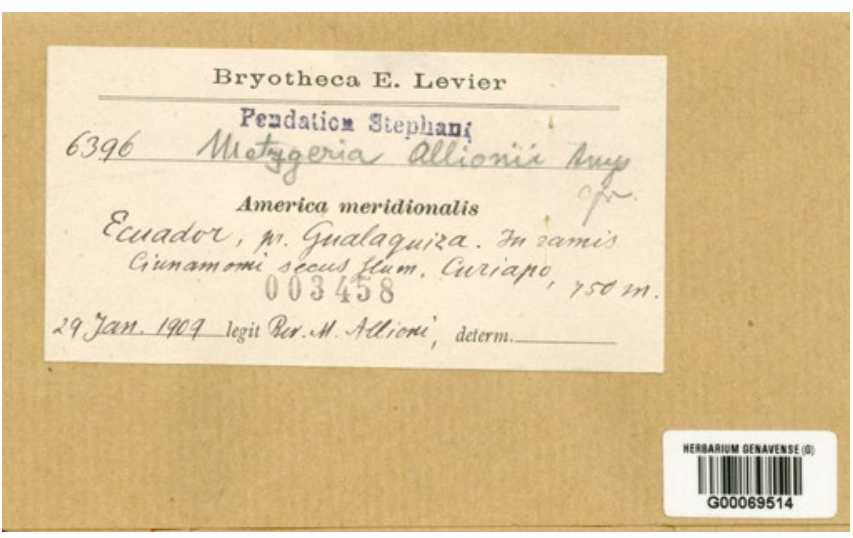

Fig. 3. - Label of holotype of Metzgeria allionii Steph. at G.

identification from Emil Levier (1838-1911), the Swiss born medical doctor and botanist in Florence who maintained a large private herbarium. The collections are kept in $\mathrm{G}$ and are labeled "Bryotheca Ecuadorensis M. Allioni" with Allioni's collecting number (Fig. 2) or "Bryotheca E. Levier" [Bryo. Levier] with Levier's herbarium number and without collecting number (Fig. 3). Specimens serving as types of new species are documented in the online Catalogue of the Geneva Herbarium (CHG, 2020). A list of the liverwort and hornwort species collected by Michel Allioni has not been published, however. Also, there is no correspondence between Allioni and Stephani in the Stephani archives kept in the library of herbarium G. All species identifications were incorporated in Species Hepaticarum (STEPHANi, 1898-1924) without citation of specimens, except for the types of new taxa which are briefly referred to in this work as "Ecuador, Allioni". Sixty-two new species were described by Stephani based on Allioni's collections, including 58 of liverworts and four of hornworts (CHG, 2020). As shown in the present paper, however, almost all new species described by Stephani were ill-defined and are synonyms. Stephani's identifications also included species that were already known (a random check of the taxonomic literature revealed five species; see below), but their total number is unknown due to the lack of a species list.

The purpose of the present paper is to present the results of our 2019 fieldwork together with a revision of the liverwort and hornwort collections made by Michel Allioni, especially those described as new species.

\section{Material and methods}

We examined about 150 collections of liverworts and hornworts from the surroundings of Gualaquiza: c. 90 collections (including 85 type specimens) made by M. Allioni during 1909-1910 and kept in G, and 60 collections kept in QCA and PC made by the authors during 30 September - 1 October 2019 (Appendix 1,2). All collections were identified or revised using the manual of the liverworts and hornworts of Colombia and Ecuador (Gradstein, in press). 


\section{Results and discussion}

\section{Collections made by Michel Allioni}

We recognized 48 species among the collections made by Allioni in the surroundings of Gualaquiza (Appendix 2). Among these are four species that were described by Stephani as new taxa based on Allioni's material: Isotachis allionii Steph. ( $\equiv$ Neesioscyphus allionii (Steph.) Grolle), Isotachis obtusa Steph., Metzgeria allionii Steph. and the hornwort Dendroceros allionii Steph. The status of the latter species requires verification, as the type (Allioni 319 [G00060907]) was on loan and not available for study. The remaining new taxa described by Stephani based on Allioni's collections, including 56 species of liverworts and two of hornworts, proved to be synonyms of earlier described taxa. Sixteen synonyms are newly proposed in this paper; the remaining synonyms were already established in previous studies and are cited in Appendix 2 with their current accepted name (except for a few names from the provinces of Azuay and Guayas; for these see Grolle, 1971; Heinrichs, 2002; Burghardt \& Gradstein, 2008; Uribe Meléndez, 2008). The high synonymy rate (93.5\%) agrees with findings of other studies on Stephani types (e.g., VERDOORN, 1934; Gradstein, 1975; Heinrichs, 2002; Dauphin, 2003; IlkiuBorges, 2016) and reflects the reckless approach of Franz Stephani in describing new species. Approximately 4000 new species of liverworts and hornworts were described by Stephani, the majority in Species Hepaticarum (STEPHANI, 1898-1924); it is estimated that more than $85 \%$ of these are synonyms (Gradstein, 2006).

The sixteen species described by Stephani based on the collections made by Michel Allioni in Ecuador and newly proposed here as synonyms are listed below.

\section{Nerw synonymies}

Diplasiolejeunea bidentiloba Steph., Sp. Hepat. 5: 922.1916, syn. nov.

Holotypus: Ecuador. Prov. Morona Santiago: Bomboiza, "frequens in silva supra Missionariorum domum", 900-950 m, 22.I.1910, Allioni 187 (G [G00040400]!).

\section{= Diplasiolejeunea brunnea Steph.}

Notes. - Diplasiolejeunea brunnea is a widespread neotropical species that is distinguished by ocellate leaves without hyaline margin, large lobules with a conspicuous, erect, fingerlike first tooth and an inconspicuous second tooth, and by deeply bifid underleaves with widely diverging, lanceolate lobes with acute tips (Reyes, 1982). Diplasiolejeunea bidentiloba, known only from the type collected by Allioni, is identical to D. brunnea. The new synonymy was already noted by R. Grolle (in sched.).
Frullania allionii Steph., Sp. Hepat. 4: 394. 1910, syn. nov.

Lectotypus (designated here): Ecuador. Prov. Morona Santiago: Gualaquiza, "in arbore silvae supra hacienda Vega”, 900 m, 13.II.1909, Allioni s.n. [Bryo. Levier 6443] (G [G00066795]!). Syntypi: ibid. loco, "forêt Liuriapa, saxicola”, 900 m, 20.VIII.1909, Allioni s.n. [Bryo. Levier 6444] (G [G00128070]!); ibid. loco, s.d., Allioni s.n. [Bryo. Levier 6565] (G [G00128071]!); ibid. loco, Bomboiza, "ad saxum erraticum vulgo "La Mesa” prope Missionariorum domum”, 900 m, 23.II.1910, Allioni 281 (G [G00128072]!).

\section{= Frullania ericoides (Nees) Nees}

Notes. - Frullania allionii is similar in all respects to the common, pantropical F. ericoides, a species standing out by brittle, squarrose leaves, lobules usually explanate (rarely helmet-shaped), and perianths with numerous small scales, lacinia or tubercles on the surface (ScHuster, 1992). The specimen in Bryo. Levier 6443 is chosen here as the lectotype of F. allionii as it was illustrated in Stephani (1985: tab. 3403).

Frullania ecuadorensis Steph., Sp. Hepat. 4: 526. 1911, syn. nov.

Holotypus: Ecuador. Prov. Guayas: "San José”, s.d., Allioni s.n. [Bryo. Levier 6551] (G [G00067443]!).

= Frullania kunzei (Lehm. \& Lindenb.) Lehm. \& Lindenb.

Notes. - Frullania kunzei is a widespread neotropical species that is distinguished by its very small size $(0.5-1 \mathrm{~mm}$ wide), prostrate growth, ovate-orbicular leaves with a rounded apex and weakly auriculate dorsal base (sub)isodiametrical apical leaf cells without intermediate thickenings, lobules 1.3-1.7 × longer than wide, small and distant underleaves, heteroiocus sexuality, and broadly 3-keeled perianths with a subentire involucre (GRADSTEIN, in press). Frullania ecuadorensis is a dioicous phenotype of F. kunzei with lobules varying from upright and close to the stem to oblique and at some distance to the stem. The close similarity of F. ecuadorensis to F. kunzei (= F. neesii Lindenb.) was already noted by STOTLER (1969).

Frullania gualaquizana Steph., Sp. Hepat. 4: 539. 1911, syn. nov.

Lectotypus (designated here): Ecuador. Prov. Morona Santiago: Gualaquiza, "in silvis", II.1909, Allioni s.n. [Bryo. Levier 6480] (G [G00068154]!). Syntypus: ibid. loco, s.d., Allioni s.n. [Bryo. Levier 6475] (G [G00265392]!).

$=$ Frullania montagnei Gottsche

Notes. - Frullania montagnei is a rather widespread neotropical species that stands out by rounded leaf tips, undivided hemiphylls, rather small and shallowly bifid underleaves 
(2-3 $\times$ stem width), and gynoecia with a subentire involucre and a 3-keeled perianth (STOTLER, 1969). Frullania gualaquizana is identical to F. montagnei and a synonym. The specimen in Bryo. Levier 6480 is chosen here as the lectotype of $F$. gualaquizana as it was illustrated in STEPHANi (1985: tab. 4038).

Lepidozia tenuicuspis Steph., Sp. Hepat. 6: 342.1922 [nom. illeg., non Spruce 1890], syn. nov.

Lectotypus (designated here): Ecuador. Prov. Morona Santiago: Gualaquiza, "in silva collis Sapotilla”, V.1909, Allioni s.n. [Bryo. Levier 6560] (G [G00112405]!). Syntypi: ibid. loco, "in silva ad rivum Salado", V.1909, Allioni s.n. [Bryo. Levier 6559] (G [G00043706]!); ibid. loco, "in silva ad rivum Sapotilla”, 9.VIII.1909, c.sp., Allioni s.n. [Bryo. Levier 6561] (G [G00112407]!).

= Lepidozia cupressina (Sw.) Lindenb.

Notes. - Lepidozia cupressina is a common and widespread Afro-American species that has been described under many different names. Lepidozia tenuicuspis Steph. is a phenotype of L. cupressina with longly uniseriate underleaf apices made up of quadrate to subrectangular cells (1-2 × longer than wide). The specimen in Bryo. Levier 6560 is chosen here as the lectotype of L. tenuicuspis as it was illustrated in STEPHANI (1985: tab. 5071).

Mastigobryum heterophyllum Steph., Sp. Hepat. 6: 466. 1924 [nom. illeg., non Colenso 1887], syn. nov.

Holotypus: Ecuador. Prov. Morona Santiago: Gualaquiza, "in silva ad rivum Salado ad truncorum arboris", V.1909, Allioni s.n. [Bryo. Levier 6577] (G [G00066890]!).

= Bazzania gracilis (Hampe \& Gottsche) Steph.

Notes. - Bazzania gracilis is a widespread neotropical species characterized by the small plants (1-2 mm wide) with strongly caducous, entire to shallowly 2-lobed leaves (Gradstein, 2017). Mastigobryum heterophyllum Steph. is identical to B. gracilis. M. H. Fulford (in sched.) already noted this synonymy, but subsequently published $M$. heterophyllum as a synonym of $B$. phyllobola Spruce (Fulford, 1963).

Plagiochila allionii Steph., Sp. Hepat. 6: 120.1917, syn. nov.

Holotypus: Ecuador. Prov. Morona Santiago: Bomboiza, "ad truncos in silvis prope Aguacate", 2200 m, IV.1910, Allioni 285 (G [G00121503]!).

= Plagiochila cristata $\left(\mathrm{Sw}_{\mathrm{.}}\right)$ Lindenb.

Notes. - Plagiochila cristata is a robust neotropical species recognized by narrowly elongate-triangular leaves with 1-2 large, apical teeth and a strongly ampliate ventral base forming a high crest (Heinrichs, 2002). Plagiochila allionii is identical to $P$. cristata and a synonym.

Plagiochila bicaudata Steph., Sp. Hepat. 6: 130.1918, syn. nov.

Lectotypus (designated here): Ecuador. Prov. Morona Santiago: Bomboiza, "frequens in silva secus rivulum Yumana ad truncos arborum", 900-1000 m, 30.I.1910, Allioni 215 (G [G00128747]!). Syntypus: ibid. loco, Gualaquiza, s.d., Allioni s.n. [Bryo. Levier 6389] (G [G00121499]!).

\section{= Plagiochila deflexirama Taylor}

Notes. - Among neotropical Plagiochila species, $P$. deflexirama stands out by densely (bi)pinnate branching with branches being predominantly of the Frullania-type, and ampliate ventral leaf bases (Gradstein, 2016). Plagiochila bicaudata is similar to $P$. deflexirama in all respects. The new lectotypification of $P$. bicaudata was already proposed by J. Heinrichs on an annotation label.

Plagiochila cobana Steph., Sp. Hepat. 6: 138. 1918, syn. nov.

Holotypus: Ecuador. Prov. Morona Santiago: Gualaquiza, Rosario, s.d., Allioni s.n. [Bryo. Levier 6490] (G [G00064144]!).

= Plagiochila rutilans Lindenb.

Notes. - Plagiochila rutilans is a common neotropical species that is distinguished by horizontally spreading, narrowly oblong-rectangular leaves with a shortly toothed apex, nonampliate ventral bases and subisodiametrical cells (HEINRICHs et al., 2001). Plagiochila cobana is identical to P. rutilans and a synonym.

Plagiochila ecuadorensis Steph., Sp. Hepat. 6: 149. 1918, syn. nov.

Holotypus: Ecuador. Morona Santiago: Gualaquiza, "in silva supra Rosario”, 1700 m, s.d., Allioni s.n. [Bryo. Levier 6363] (G [G00061382]!).

= Plagiochila deflexa Mont. \& Gottsche

Notes. - Plagiochila deflexa is an uncommon neotropicalHawaiian species that is recognized by elongate-triangular leaves with a large vitta-like area near the base, a narrowly truncate apex, margins with rather few teeth (frequently two larger teeth at apex), and longly decurrent, ampliate ventral bases (Heinrichs et al., 2002). The species was described from Ecuador as P. chimborazensis Spruce and P. ecuadorensis Steph., which are synonyms (Gradstein, in press). 
Plagiochila matanga Steph., Sp. Hepat. 6: 183. 1921, syn. nov.

Holotypus: Ecuador. Prov. Azuay: páramo del Matanga, s.d., Allioni 679 (G [G00064204]!).

$=$ Plagiochila longispina Lindenb. \& Gottsche

Notes. - Plagiochila longispina is a neotropical-montane species that is distinguished by more or less bluish stems, and leaves with numerous long-linear teeth all around the margins (Heinrichs et al., 2000). Plagiochila matanga is identical to $P$. longispina and a synonym.

Plagiochila nova Steph., Sp. Hepat. 6: 189. 1921, syn. nov.

Lectotypus (designated here): Ecuador. Prov. Morona

Santiago: Bomboiza, "frequens ad terram et ad truncos putrescentes in Granadillas", 2500 m, 15.XI.1910, Allioni 709 (G [G000061534]!).

\section{= Plagiochila montagnei Nees}

Notes. - Plagiochila montagnei is a common neotropical rainforest species that is recognized by terminal branching and ovate-lingulate leaves with a longly decurrent dorsal base, toothed ventral and apical margins, and strongly ampliate ventral bases with triangular teeth (HeinRichs \& Gradstein, 2000). The species is common in lowland forests and is only occasionally seen in montane forests. The specimen Allioni 709 is chosen here as the lectotype of $P$. nova as it was illustrated in Stephani (1985: tab. 11214). A further syntype (Bomboiza, "frequens ad truncos in silva M. Sapotilla prope domum bonbori”, 1000 m, 21.X.1910, Allioni 651, G [G00113038]!) belongs to $P$. macrostachya Lindenb.

Plagiochila paludosa Steph., Sp. Hepat. 6: 195.1921, syn. nov.

Lectotypus (designated here): Ecuador. Prov. Morona Santiago: Gualaquiza, "in paludosis fluvii Rio Salado", 10.II.1909, Allioni s.n. [Bryo. Levier 6358] (G [G00121456]!). Syntypi: ibid. loco, "in trunco arboris silvae supra G. Vega”, 13.I.1909, Allioni s.n. [Bryo. Levier 6371] (G [G00121490]!); ibid. loco, "in silva ad rivum Sapotilla", IX.1910, Allioni s.n. [Bryo. Levier 6618] (G [G00128758]!); ibid. loco, "in silva densiore obscura, collis Sapotilla”, V.1909, Allioni s.n. [Bryo. Levier 6628] (G [G00128759]!); ibid. loco, "in via ad Rosario", VI.1909, Allioni s.n. [Bryo. Levier 6606] (G [G128760]!).

$=$ Plagiochila heteromalla Lindenb.

Notes. - Plagiochila heteromalla is widespread in the Andes and is distinguished by the (sub)opposite and usually strongly secund leaves with a border of thick-walled cells, a vitta-like basal area, shortly toothed margins, shortly decurrent leaf bases and homogeneous oil bodies (Gradstein, 2016). Plagiochila paludosa is identical to $P$. heteromalla and a synonym. The new lectotypification of P. paludosa was already proposed by J. Heinrichs on an annotation label.

Scapania minutidens Steph., Sp. Hepat. 6: 503.1924, syn. nov.

Holotypus: Ecuador. Prov. Morona Santiago: Bomboiza, "in superioribus montis Aguacate", in truncis in arborum silvis, 2400-2600 m, IV.1910, Allioni 291 (G [G00124058]!).

= Scapania portoricensis Hampe \& Gottsche

Notes. - Scapania portoricensis is the only neotropical member of the large, holarctic genus Scapania (Dumort.) Dumort. and characteristic of upper montane cloud forests (Frahm \& Gradstein, 1991). The species is readily recognized by its reddish color, large size (to $20 \mathrm{~cm}$ long and $1 \mathrm{~cm}$ wide), toothed leaf margins, very short keel and stellate gemmae. Scapania minutidens is a robust phenotype of S. portoricensis.

Taxilejeunea auriculata Steph., Sp. Hepat. 5: 459.1914, syn. nov.

Lectotypus (designated here): Ecuador. Prov. Morona Santiago: Gualaquiza, "in silva Churiacu, ad arborum corticum”, IX.1909, Allioni s.n. [Bryo. Levier 6534] (G [G00064193]!). Syntypus: Costa Rica: San José, Tablazo, 1900 m, 4.III.1908, Brade s.n. (G [G00283254]!).

= Lejeunea rotundifolia Mitt.

Notes. - Lejeunea rotundifolia is a robust Andean species with orbicular leaves, very large and suborbicular underleaves with a short-bifid apex and strongly auriculate bases, and stems with 4-6 cell wide ventral merophytes (REINER-Drehwald, 2005). Taxilejeunea auriculata is identical to $L$. rotundifolia and a synonym. The specimen collected by Allioni is chosen here as the lectotype of T. auriculata as it was illustrated in STEPHANI (1985: tab. 9997).

Taxilejeunea tenuiplica Steph., Sp. Hepat. 5: 480.1914, syn. nov.

Holotypus: Ecuador. Prov. Morona Santiago: Gualaquiza, "in silva secus rivum Gualaquiza", s.d.,Allioni s.n. [Bryo. Levier 6647] (G [G000047597]!).

$=$ Lejeunea flava $(\mathrm{Sw}$.$) Nees$

Notes. - Lejeunea flava is widely distributed in tropical and warm-temperate regions of the world and distinguished by ovate-oblong leaves with rounded tips, leaf cells with conspicuous trigones, \pm longer than wide underleaves with a cordate base, and gynoecia frequently two in a row on short branches (e.g., Schuster, 1980). Stephani's description of Taxilejeunea 
tenuiplica adds another name to the long list of synonyms of L. flava.

\section{Invalid name}

Hygrolejeunea fissistipula Steph. ex Bonner, Index Hepat 6: 650. 1966 [nom. nud.].

Original material: Ecuador. Prov. Morona Santiago: Bomboiza, "in silva Sacramento frequens", $900 \mathrm{~m}$, 14.II.1910, Allioni 254 (G [G00280827]!).

$=$ Otigoniolejeunea huctumalcensis (Lindenb. \& Gottsche) Y.M. Wei et al.

Notes. - Otigoniolejeunea huctumalcensis is an uncommon neotropical species that was long considered a member of Ceratolejeunea Jack \& Steph. (as C. dussiana Steph. = C. dentatocornuta Steph.; Dauphin, 2003) until Wei et al. (2014) showed its position in Otigoniolejeunea (Spruce) Schiffn. based on molecular evidence. Characteristic are the delicate plants with ocellate leaves, small bottle-shaped lobules, distant bifid underleaves and perianths with antler-like laciniae. Hygrolejeunea fissistipula is identical to O. huctumalcensis.

\section{Notes on taxa collected by Allioni}

Many of the species described as new by Stephani based on Allioni's collections are common and widespread, e.g., Bazzania hookeri (Lindenb.) Trevis., B. stolonifera (Sw.) Trevis., Frullania ericoides (Nees) Nees, F. kunzei (Lehm. \& Lindenb.) Lehm. \& Lindenb., Isotachis multiceps (Lindenb. \& Gottsche) Gottsche, I. serrulata (Sw.) Gottsche, Leiomitra tomentosa (Sw.) Lindb., Lejeunea flava (Sw.) Nees, Lepidozia cupressina (Sw.) Lindenb., Metzgeria leptoneura Spruce, Odontolejeunea lunulata (F. Weber) Schiffn., Phaeoceros carolinianus (Michx.) Prosk., Plagiochila adianthoides (Sw.) Lindenb., P. aerea Taylor, $P$. raddiana Lindenb., Scapania portoricensis Hampe \& Gottsche and Syzygiella rubricaulis (Nees) Steph. A few new species, however, are uncommon taxa that are known from only few collections and have restricted distributions. They include the following taxa:

Archilejeunea ludoviciana (Lehm.) Geissler \& Gradst. subsp. ludoviciana

Notes. - This liverwort is characteristic of the Chocó biogeographic region of Colombia and Ecuador, and additionally occurs in the eastern foothills of the northern Andes ( $\mathrm{SHI}_{\mathrm{H}} \&$ ZHu, 2005). Allioni collected this subspecies twice along the Río Sapotillo; one collection was described by Stephani as a new species of Leucolejeunea, the other one as a new species of Marchesinia.

\section{Dendroceros allionii Steph.}

Notes. - Only known from the type collected by Allioni along the Río Gualaquiza. The status of this species needs further study; the type has been on loan and was not available for examination.

\section{Frullania confertiloba Steph.}

Notes. - A rare neotropical species, in Ecuador only known from Gualaquiza where it was found by Allioni along the Río Yumana (YuZAwa, 1991).

\section{Frullania mirabilis Jack \& Steph.}

Notes. - An uncommon northern Andean species, ranging northwards to Costa Rica. In Ecuador only known from Gualaquiza and Parque National Podocarpus and surrounding areas (Schäfer-Verwimp et al., 2013).

\section{Isotachis obtusa Steph.}

Notes. - This rare aquatic high Andean species was first detected by Allioni in the páramo of Matanga, in the province of Azuay. The species has usually been called I. lacustris Herzog, which is a synonym of I. obtusa (GRADSTEIN, in press).

\section{Lepidozia pseudocupressina Schiffn.}

Notes. - This rare species is only known from southern Brazil and from Ecuador, where Allioni found it in Morona Santiago (Gualaquiza) and Azuay. The species is very close to the common L. cupressina and may be a variety of the latter (Gradstein, in press).

\section{Metzgeria allionii Steph.}

Notes. - Only known from the type from Gualaquiza, where it was collected by Allioni along the Río Curiapo. The species is very similar to the widespread but uncommon M. crassipilis (Lindb.) A. Evans - found by the authors along the Río Bomboiza and Río Quimi in 2019 - but differs in gemmae and younger parts of the thallus with falcate hairs (Kuwahara, 1986; Costa, 2008).

\section{Neesioscyphus allionii (Steph.) Grolle}

Notes. - This rare northern Andean species was first gathered by Allioni near Gualaquiza along the Río San José. 


\section{Plagiochila deflexa Mont. \& Gottsche}

Notes. - A species with an unusual distribution, being common in Hawaii and additionally found in Central America (Heinrichs et al., 2002) and in the northern Andes, where it is rare (GRADSTEIN, in press). The collection made by Allioni, near Rosario along the road from Gualaquiza to Azuay, is the southernmost record of the species.

\section{Pycnolejeunea densistipula (Lehm. \& Lindenb.) Steph.}

Notes. - An uncommon neotropical species occurring in southeastern Brazil and the Ecuadorian Andes, where it is known from Reserva Biológica San Francisco, Zamora Chinchipe (PArolly et al., 2004) and Gualaquiza, where Allioni found it along the Río San Francisco.

\section{Collections made by the authors}

Our collections from the surroundings of Gualaquiza yielded 66 species, including 64 of liverworts and two of hornworts (Annexe 2). Of these, three species, Lejeunea rionegrensis Spruce, Notothylas javanica (Sande Lac.) Gottsche and Riccia vitalii Jov.-Ast, are new to Ecuador and 37 (c. $60 \%$ ) are new to the prov. of Morona Santiago. Lejeunea rionegrensis is a rather widespread, but uncommon Amazonian species that was known from Venezuela, Brazil, Ecuador, Peru and Bolivia (Reiner-Drehwald \& Schäfer-Verwimp, 2008). Its occurrence in Ecuador was therefore to be expected. Riccia vitalii is a characteristic species of dry caatinga of eastern Brazil that has rarely been found elsewhere (Paraguay, northern Colombia, Costa Rica; Gradstein et al., 2016). Notothylas javanica, finally, is a pantropical species with a limited distribution in the Neotropics, where it is known from central and eastern Brazil and northern Colombia. The species was known in the Neotropics as $N$. vitalii Udar \& D.K. Sing, which is a synonym (Leandro de Almeida \& Peralta, 2020). The latter species had already been reported from Ecuador, but the Ecuadorian specimens were misidentified (GRADSTEIN et al., 2016).

Three further species in our collections, Jensenia difformis (Nees) Grolle, Myriocoleopsis gymnocolea (Spruce) M.E. Reiner \& Gradst. and Riccia crassifrons Spruce, are very rare in Ecuador. Jensenia difformis is a southern temperate species that is in the Neotropics only known from southeastern Brazil and the northern Andes, where it is uncommon. In Ecuador the species had been recorded once (PArolly et al., 2004). Riccia crassifrons is an Amazonian species that had been found once in Ecuador along the Río Nangaritza (Benitez \& Gradstein, 2011) and Myriocoleopsis gymnocolea is a rheophytic species from southeastern Brazil and northern Argentina, that is known from three localities in Ecuador (Reiner-Drehwald \& Gradstein, 1997; Gradstein et al., 2011). A further uncommon species, Phaeoceros tenuis (Spruce)
Hässel, was collected by the authors on 2 October 2019 along the road Macas - Puyo, c. $1 \mathrm{~km}$ before the bridge across the Río Pastaza (P11614, QCA). This is the second record from Ecuador of this rare neotropical hornwort.

The number of species of liverworts and hornworts recorded from Morona Santiago has been raised to c. 190 based on the collections made by the authors. In comparison, the country of Ecuador counts about 700 species and several provinces have more recorded species than Morona Santiago (LÉon-YÁnez et al., 2006; Gradstein, in press). The results indicate that Morona Santiago, in spite of being one of the largest provinces of Ecuador, is still very incompletely collected for liverworts and hornworts. This conclusion is supported by a comparison of the species collected by Michel Allioni and by the authors (Table 1). Of 48 species gathered by Allioni, only eight were found by us; 40 species or almost $80 \%$ of those found by Allioni were not seen during our visit. An explanation may be the greater number of localities, habitats and different elevations inventoried by Allioni. On the other hand, 58 species were collected during our brief, 2-days visit to the Gualaquiza area that were lacking in the collections of Allioni examined in this study. These figures are suggestive of the incompleteness of our knowledge of the liverworts and hornwort flora of the Gualaquiza area. However, our data are biased by the rather limited set of Allioni specimens examined in this study, which was mainly restricted to type specimens. A search of the non-type collections of liverworts and hornworts in herbarium $\mathrm{G}$ might yield additional species of liverworts and hornworts collected by Michel Allioni during his pioneering exploration of the bryophyte flora of Gualaquiza.

\section{Acknowledgments}

We are grateful to Wilson Paucar and Juan Carlos Fernández (Ministerio del Ambiente de Ecuador) for allowing and joining us to collect in the surroundings of Gualaquiza including El Quimi Biológical Reserve. We also thank Angel Benitez and Jorge Deleg (Universidad Técnica Particular de Loja) for accompanying us in the field. The first author expresses his gratitude to Michelle J. Price (Conservatoire et Jardin botaniques de Genève) for hosting his stay in herbarium $\mathrm{G}$ for the study of the collections of Michel Allioni and for constructive comments on the manuscript, to Agathe Gautschi (Conservatoire et Jardin botaniques de Genève) and Françoise López (Muséum national d'Histoire naturelle, Paris) for technical assistance and help with the figures, and to the editor of Candollea, Martin W. Callmander, for correcting the manuscript. 


\section{References}

Allioni, M.(1909). Da Guayaquil a Gualaquiza. Bolletino Salesiano 5: 145-147.

Allioni, M. (1978). La vida del pueblo Shuar (edited by J. Botasso). Mundo Shuar E, 6: 1-170.

Allioni, M. (1993). La vida del pueblo Shuar. In: Bottasso, J. (ed.), Los Salesianos y la Amazonia, Tomo 1: Relaciones etnográfica y geográficas: 23-162. Ediciones Abya Yala, Quito.

Benitez, A. \& S.R. Gradstein (2011). Adiciones a la flora de briófitas del Ecuador. Cryptog., Bryol. 32: 65-74.

Bottasso, J. (1993). Los Salesianos y la Amazonia. Ediciones Abya Yala, Quito.

Brotherus, V. F. (1911). Allioniella, eine neue Laubmoosgattung aus Ecuador. Oefvers. Förh. Finska Vetensk.-Soc. 53: 1-4.

Brotherus, V.F. (1920). Contributions à la flore bryologique de l'Ecuador. Rev. Bryol. Lichénol. 47: 1-16, 35-46.

Burghardt, M. \& S.R. Gradstein (2008). A revision of Tylimanthus in tropical America, Africa and Macaronesia. Fieldiana, Bot. n.s. 47: 199-210.

CHG [Catalogue des herbiers de Genève] (2020). Conservatoire et Jardin botaniques de la Ville de Genève. [http://www. ville-ge.ch/musinfo/bd/cjb/chg]

Churchill, S.P., D. Griffin III \& J. Muñoz (2000). Checklist of the mosses of the tropical Andean countries. Ruizia 17: 1-203.

Costa, D.P. (2008). Metzgeriaceae. Fl. Neotrop. Monogr. 102.

Creamer, P. (2011). P. Allioni Miguel (1880-1912). Noticier. Salesiano Ecuador 372: 24. [https://issuu.com/salesianosec/docs/octubre_ noticiero]

Dauphin, G. (2003). Ceratolejeunea. Fl. Neotrop. Monogr. 90.

Frahm, J.P. \& S.R. Gradstein (1991). An altitudinal zonation of the tropical rain forest using bryophytes. J. Biogeogr. 18: 669-678.

Fulford, M.H. (1963). Manual of the leafy Hepaticae of Latin America I. Mem. Nerw York Bot. Gard. 11: 1-172.

García, L. (1999). Historia de las Misiones en la Amazonia Ecuatoriana. Ed 2. Ediciones Abya Yala, Quito.

Gradstein, S.R. (2006). Stephani's Species Hepaticarum revisited. Willdenowia 36: 557-563.

Gradstein, S.R. (2016). The genus Plagiochila (Marchantiophyta) in Colombia. Rev. Acad. Colomb. Cienc. Ex. Fis. Nat. 40: 104-136.

Gradstein, S.R. (2017). Bazzania (Marchantiophyta) in South America. Nova Hedwigia 105: 243-266.

Gradstein, S.R. (in press). The liverworts and hornworts of Colombia and Ecuador. Mem. New York Bot. Gard.
Gradstein, S.R. \& A. Benitez (2017). Liverworts new to Ecuador with description of Plagiochila priceana sp. nov. and Syzygiella burghardtii sp. nov. Cryptog., Bryol. 38: 335-348.

Gradstein, S.R., A.L. Ilkiu-Borges \& A. Vanderpoorten (2011). Habitat specialization triggers the evolution of unusual morphologies: the case of Cololejeunea stotleriana sp. nov. from Ecuador. Bryologist 114: 9-22.

Gradstein, S.R., C. Morales, M.A. Negritto \& J.G. Duckett (2016). New records of liverworts and hornworts from the Sierra Nevada de Santa Marta, Colombia. Cryptog., Bryol. 37: 463-475.

Gradstein, S.R., C. Reeb, A.J. Pérez, N. Zapata \& C. Persson (2019). A new dendroid species of Riccardia (Marchantiophyta: Aneuraceae) from Ecuador. J. Bryol. 41: 322-327.

Grolle, R. (1971). Jamesoniella und Verwandte. Feddes Repert. 82: 1-99.

Heinrichs, J. (2002). A taxonomic revision of Plagiochila sect. Hylacoetes, sect. Adiantoideae and sect. Fuscoluteae in the Neotropics, with a preliminary subdivision of neotropical Plagiochilaceae into nine lineages. Bryophyt. Biblioth. 58.

Heinrichs, J. \& S.R. Gradstein (2000). A revision of Plagiochila sect. Crispatae and sect. Hypnoides (Hepaticae) in the Neotropics. I. Plagiochila disticha, P. montagnei and P. raddiana. Nova Hedwigia 70: 161-184.

Heinrichs, J., H. Anton, I. Holz \& S.R. Gradstein (2000). On the blue stem colour in Plagiochila longispina Lindenb. \& Gottsche (Plagiochilaceae). Cryptog., Bryol. 21: 109-111.

Heinrichs, J., H. Groth, S.R. Gradstein, D.S. Rycroft, W.J. Cole $\&$ H. Anton (2001). Plagiochila rutilans (Hepaticae): a poorly known species from tropical America. Bryologist 104: 350-361.

Heinrichs, J., H. Groth, I. Holz, D.S. Rycroft, C. Renker \& T. Pröschold (2002). The systematic position of Plagiochila moritziana, P. trichostoma and P. deflexa, based on ITS sequences of nuclear ribosomal DNA, morphology and lipophylic secondary metabolites. Bryologist 105: 189-203.

Ilkiu-Borges, A.L. (2016). Prionolejeunea. Fl. Neotrop. Monogr. 116.

Koponen, T. \& S. Piippo (2002). Viktor Ferdinand Brotherus and his collection of letters. Bryobrotherella 5: 1-29.

Kuwahara, Y.(1986). The Metzgeriaceae of the Neotropics. Bryophyt. Biblioth. 28: 1-254.

Leandro de Almeida, A. \& D.F. Peralta (2020). The genus Notothylas (Notothyladaceae, Anthocerotophyta) in Brazil. Brazilian J. Bot. 43: 331-340. [https://doi.org/10.1007/s40415-020-00602]

León-Yánez, S., S.R. Gradstein \& C. Wegner (2006). Hepáticas y Antoceros del Ecuador. Herbario QCA, Quito.

Mazabanda, C., R. Kemper, A. Thieme, B. Hettler \& M. Finer (2020). Impacts of mining project "Mirador" in the Ecuadorian Amazon. [https://maaproject.org/mirador-ecuador] 
Ochyra, R. (1982). New names for genera of mosses. J. Bryol. 12: 31-32.

Parolly, G., H. Kürschner, A. Schäfer-Verwimp \& S.R. Gradstein (2004). Cryptogams of the Reserva Biológica San Francisco (Prov. Zamora-Chinchipe, Southern Ecuador). III. Bryophytes - Supplement. Cryptog., Bryol. 25: 271-289.

Pérez, A.J., C. Persson, N. Zapata, B. Mashburn \& J.A. VÁzquesGarcía (2020). Magnolia lozanoi (Magnolia subsect. Dugandiodendron, Magnoliaceae), rediscovered on Ecuadorian "tepuis" in Reserva Biológica E1 Quimi, Cordillera del Cóndor: critically endangered by open-pit mining. Phytotaxa 428: 255-262.

Reiner-Drehwald, M.E. (2005). On Lejeunea rotundifolia and Dicladolejeunea (Lejeuneaceae, Jungermanniopsida). Syst. Bot. 30: 687-692.

Reiner-Drehwald, M.E. \& S.R. Gradstein (1997). New combinations and synonyms in Myriocoleopsis Schiffn. (Lejeuneaceae). J. Bryol. 19: 638-640.

Reiner-Drehwald, M.E. \& A. Schäfer-Verwimp (2008). Lejeunea oligoclada and L. rionegrensis (Lejeuneaceae) in tropical America: New data on morphology and geographical distribution. Nova Hedwigia 87: 175-184.

Renner, S.S. (1993). History of botanical exploration in Amazonian Ecuador. Smithsonian Contr. Bot. 82: 1-39.

Reyes, D.M. (1982). El género Diplasiolejeunea en Cuba. Acta Bot. Acad.-Sci. Hung. 28: 145-180.

Roy B.A., M. Zorilla, L. Endara, D.C. Thomas, R. Vandegrift, J.M. Rubenstein, T. Policha, B. RÍo-Touma \& M. Read (2018). New mining concessions could severely decrease biodiversity and ecosystem services in Ecuador. J. Cons. Sci. 11: 1-20.

Schäfer-Verwimp, A., M. Lehnert \& M. Nebel (2013). Contribution to the knowledge of the bryophyte flora of Ecuador. Phytotaxa 128: 1-63.

Schuster, R.M. (1980). The Hepaticae and Anthocerotae of North America IV. Columbia University Press, New York.

Schuster, R.M. (1992). The Hepaticae and Anthocerotae of North America V. Field Museum of Natural History, Chicago.

Shi, X.Q. \& R.L. Zhu (2005). A revision of Archilejeunea s.str. (Lejeuneaceae, Marchantiophyta). Nova Hedwigia 100: 589-601.

Steere, W.C. (1948). Contribution to the bryogeography of Ecuador. I. A review of the species of Musci previously reported. Bryologist 51: $65-167$.

Stephani, F. (1898-1924). Species Hepaticarum. 6 vol. Genève, Bâle.

Stephani, F. (1985). Icones Hepaticarum. Microfiche edition. IDC, Zug.

Stotler, R.E. (1969). The genus Frullania subgenus Frullania in Latin America. Nova Hedwigia 18: 397-555.
Uribe Meléndez, J. (2008). Monografía de Frullania subgénero Meteoriopsis (Frullaniaceae, Marchantiophyta). Caldasia 30: 49-94.

Verdoorn, F. (1934). Studien über Asiatische Jubuleae. Ann. Bryol. Suppl. 4: 1-231.

Wei, Y., R.L. Zhu \& S.R. Gradstein (2014). Notes on early land plants today. 47. On Lejeunea huctumalcensis Lindenb. $\&$ Gottsche and the resurrection of Otigoniolejeunea (Spruce) Schiffn., an older name for Physantholejeunea R.M. Schust. (Marchantiophyta, Lejeuneaceae). Phytotaxa 162: 236-238.

Yuzawa, Y. (1991). A monograph of subgen. Chonanthelia of gen. Frullania (Hepaticae) of the world. J. Hattori Bot. Lab. 70: 181-291.

\section{Appendix 1. - Localities.}

Localities of M. Allioni collections (G)

Collected during 1909-1910 in the surroundings of Gualaquiza (Ecuador, prov. Morona Santiago), at 750-1200 m elevation unless stated otherwise.

$\mathrm{AO}=$ Gualaquiza (without further detail).

$A 1=$ Surroundings of Salesian mission house.

A2 = Río Gualaquiza.

$\mathrm{A} 3=$ Río San Francisco, Hacienda of G. Vega.

A4 = Río Churiacu.

$\mathrm{A} 5=$ Río Curiapo.

A6 = Río San José.

A7 = Río Yumana.

A8 = Río Salado.

A9 = Río Sapotillo and Mt. Sapotillo.

A10 $=$ Guayusa forest.

A11 = Liuriapa forest.

A12 $=$ Tres Cruces.

A13 $=$ Sacramento

A14 = Rosario (1500-1700 m).

A15 $=$ Granadillo $(2400-3000 \mathrm{~m})$.

A16 = Aguacate $(2200-2600 \mathrm{~m})$.

Localities of S.R. Gradstein \& A.J. Pérez

Collections from the surroundings of Gualaquiza (QCA, PC)

$1=\quad$ Along Río Quimi, trail to the cascade, $3^{\circ} 50.28^{\prime} \mathrm{S}, 78^{\circ} 42.75^{\prime} \mathrm{W}$, 1000-1100 m, 30.IX.2019.

$2=$ Mixed cacao garden, $\mathrm{S}$ of Gualaquiza town, $3^{\circ} 42.32^{\prime} \mathrm{S}$, 7857.01'W, 850 m, 1.X.2019.

$3=$ Cacao plantation and roadside, Bomboiza village, $3^{\circ} 45.55$ 'S, 7854.55'W, 850 m, 1.X.2019.

$4=$ Along Río Bomboiza, Bomboiza village, $3^{\circ} 45.55$ 'S, $78^{\circ} 54.55^{\prime} \mathrm{W}$, 850 m, 1.X.2019. 
Appendix 2. - Species of liverworts (Marchantiophyta) and hornworts (Anthocerotophyta) recorded from the surroundings of Gualaquiza, Ecuador (prov. of Morona Santiago) by M. Allioni (localities A0-A16) and the authors (localities 1-4).

Bold face = new to Ecuador; * = new to Prov. Morona Santiago. Synonyms = original names of Allioni specimens. Allioni specimens are kept in G, those made by the authors in QCA. For explanation of localities see Appendix 1.

\begin{tabular}{|c|c|c|c|}
\hline Accepted name & Synonym(s) & Localities & Collections studied \\
\hline \multicolumn{4}{|l|}{ MARCHANTIOPHYTA } \\
\hline $\begin{array}{l}\text { Archilejeunea ludoviciana (Lehm.) Geissler \& Gradst. } \\
\text { subsp. ludoviciana }\end{array}$ & $\begin{array}{l}\text { Leucolejeunea ecuadorensis } \\
\text { Steph., Marchesinia longistipula } \\
\text { Steph. }\end{array}$ & A9 & $\begin{array}{l}\text { Allioni s.n. [Bryo. Levier 6523, } \\
6569]\end{array}$ \\
\hline *Anoplolejeunea conferta (Meissn.) Schiffn. & & 1 & Gradstein \& Pérez 11596 p.p. \\
\hline Bazzania gracilis (Hampe \& Gottsche) Steph. & $\begin{array}{l}\text { Mastigobryum heterophyllum } \\
\text { Steph. }\end{array}$ & A8 & Allioni s.n. [Bryo. Levier 6577] \\
\hline Bazzania hookeri (Lindenb.) Trevis. & $\begin{array}{l}\text { Mastigobryum ecuadorense } \\
\text { Steph. }\end{array}$ & $\mathrm{A} 1, \mathrm{~A} 15$ & $\begin{array}{l}\text { Allioni 353, s.n. [Bryo. Levier } \\
6406,6578 \text { ] }\end{array}$ \\
\hline Bazzania stolonifera (Sw.) Trevis. & Mastigobryum azuayense Steph. & A8 & Allioni s.n. [Bryo. Levier 6570] \\
\hline Bryopteris diffusa (Sw.) Nees & & $1,2,3$ & Gradstein \& Pérez 11556, 11592 \\
\hline Bryopteris filicina (Sw.) Nees & & A9 & Allioni s.n. [Bryo. Levier 6543] \\
\hline Cephalozia crossii Spruce & Cephalozia patentiloba Steph. & $\mathrm{A} 15$ & Allioni 708 \\
\hline Cephaloziopsis intertexta (Gottsche) R.M. Schust. & & 1 & Gradstein \& Pérez 11587 \\
\hline Ceratolejeunea cornuta (Lindenb.) Schiffn. & & 1,4 & Gradstein \& Pérez 11572, 11581 \\
\hline Ceratolejeunea cubensis (Mont.) Schiffn. & $\begin{array}{l}\text { Ceratolejeunea granatensis } \\
\text { Steph. }\end{array}$ & $\mathrm{A} 1$ & Allioni s.n. [Bryo. Levier 6543] \\
\hline${ }^{\star}$ Ceratolejeunea filaria (Lehm.) Steph. & & 1,4 & Gradstein \& Pérez 11571, 11580a \\
\hline Cheilolejeunea filiformis (Sw.) W. Ye et al. & & 1,3 & Gradstein \& Pérez 11580 \\
\hline *Cheilolejeunea holostipa (Spruce) Grolle \& R.L. Zhu & & 4 & Gradstein \& Pérez 11580b \\
\hline *Cheilolejeunea rigidula (Nees \& Mont.) R.M. Schust. & & 2 & Gradstein \& Pérez 11559 \\
\hline Cheilolejeunea trifaria (Reinw. et al.) Mizut. & & 3 & Gradstein \& Pérez 11560b \\
\hline $\begin{array}{l}\text { ^Cyclolejeunea convexistipa (Lehm. \& Lindenb.) } \\
\text { A. Evans }\end{array}$ & & 1 & Gradstein \& Pérez 11605a \\
\hline Diplasiolejeunea brunnea Steph. & $\begin{array}{l}\text { Diplasiolejeunea bidentiloba } \\
\text { Steph. }\end{array}$ & A1 & Allioni 187 \\
\hline Drepanolejeunea inchoata (Meissn.) Steph. & & 1,4 & $\begin{array}{l}\text { Gradstein \& Pérez 11568, 11596, } \\
11602\end{array}$ \\
\hline *Drepanolejeunea infundibulata (Spruce) Steph. & & 1 & $\begin{array}{l}\text { Gradstein \& Pérez 11594, 11604, } \\
11605\end{array}$ \\
\hline *Dumortiera hirsuta (Sw.) Nees & & 1 & Gradstein \& Pérez 11589 \\
\hline *Fossombronia porphyrorhiza (Nees) Prosk. & & 1 & Gradstein \& Pérez 11573 \\
\hline Frullania confertiloba Steph. & Frullania bomboizana Steph. & A7 & Allioni 196 \\
\hline Frullania ericoides (Nees) Nees & Frullania allionii Steph. & $\begin{array}{l}A 1, A 3, A 11, \\
2,3\end{array}$ & $\begin{array}{l}\text { Allioni 281, Allioni s.n. } \\
\text { [Bryo. Levier 6443, 6444, 6565], } \\
\text { Gradstein \& Pérez 11554, } 11560 \text { a }\end{array}$ \\
\hline $\begin{array}{l}\text { Frullania macrocephala (Lehm. \& Lindenb.) } \\
\text { Lehm. \& Lindenb. }\end{array}$ & & $\mathrm{A} 0,1,2$ & $\begin{array}{l}\text { Allioni s.n. [Bryo. Levier 6515], } \\
\text { Gradstein \& Pérez 11559, 11580b }\end{array}$ \\
\hline Frullania mirabilis Jack \& Steph. & Frullania pendulostyla Steph. & $\mathrm{A} 10$ & Allioni 600bis \\
\hline
\end{tabular}




\begin{tabular}{|c|c|c|c|}
\hline Accepted name & Synonym(s) & Localities & Collections studied \\
\hline Frullania montagnei Gottsche & $\begin{array}{l}\text { Frullania auritistipula Steph., } \\
\text { F. gualaquizana Steph., } \\
\text { F. purpurascens Steph. }\end{array}$ & AO & $\begin{array}{l}\text { Allioni s.n. [Bryo. Levier 6452, } \\
6463,6475,6480 \text { ] }\end{array}$ \\
\hline Frullania rio-janeirensis Raddi & & 2,3 & Gradstein \& Pérez 11553 \\
\hline *Frullania exilis Taylor & & 1 & Gradstein \& Pérez 11596 p.p. \\
\hline Harpalejeunea stricta (Lindenb. \& Gottsche) Steph. & & 1 & Gradstein \& Pérez 11577 \\
\hline Heteroscyphus marginatus (Steph.) Fulford & $\begin{array}{l}\text { Chiloscyphus bomboizanus } \\
\text { Steph. }\end{array}$ & A15 & Allioni 685 \\
\hline Isotachis multiceps (Lindenb. \& Gottsche) Gottsche & Cephalozia hians Steph. & A1 & Allioni 532 \\
\hline Isotachis serrulata (Sw.) Gottsche & Isotachis ecuadorensis Steph. & $\begin{array}{l}\text { A4, A7, } \\
\text { A14, A1 }\end{array}$ & $\begin{array}{l}\text { Allioni 365, 474, s.n., } \\
\text { [Bryo. Levier 6522, 6540] }\end{array}$ \\
\hline *Jensenia difformis (Nees) Grolle & & 1 & Gradstein \& Pérez 11613 \\
\hline Leiomitra tomentosa (Sw.) Lindb. & Trichocolea allionii Steph. & $\mathrm{A} 14, \mathrm{~A} 15,1$ & $\begin{array}{l}\text { Allioni 697b, s.n. [Bryo. Levier } \\
6351,6643 \text { ], Gradstein \& Pérez } \\
11600\end{array}$ \\
\hline Lejeunea aphanes Spruce & & 4 & Gradstein \& Pérez 11567 \\
\hline *Lejeunea caripensis Lindenb. \& Gottsche & & 1 & Gradstein \& Pérez 11580 p.p. \\
\hline *Lejeunea flaccida Lindenb. \& Gottsche & & 4 & Gradstein \& Pérez 11569 \\
\hline Lejeunea flava (Sw.) Nees & Taxilejeunea tenuiplicata Steph. & $\mathrm{A} 2,1$ & $\begin{array}{l}\text { Allioni s.n. [Bryo. Levier 6647], } \\
\text { Gradstein \& Pérez 11565, 11575, } \\
11595\end{array}$ \\
\hline Lejeunea laetevirens Nees \& Mont. & & 1,3 & $\begin{array}{l}\text { Gradstein \& Pérez } 1560 \text { b p.p., } \\
11603 \text { p.p. }\end{array}$ \\
\hline Lejeunea phyllobola Nees \& Mont. & & 1,2 & $\begin{array}{l}\text { Gradstein \& Pérez } 11560 \text { b p.p., } \\
11603\end{array}$ \\
\hline $\begin{array}{l}\text { Lejeunea reflexistipula (Lehm. \& Lindenb.) } \\
\text { Gottsche et al. }\end{array}$ & & 1 & Gradstein \& Pérez 11596 \\
\hline *Lejeunea rionegrensis Spruce & & 4 & Gradstein \& Pérez 11570 \\
\hline Lejeunea rotundifolia Mitt. & Taxilejeunea auriculata Steph. & $A 4,3$ & $\begin{array}{l}\text { Allioni s.n. [Bryo. Levier 6396], } \\
\text { Gradstein \& Pérez s.n. }\end{array}$ \\
\hline Lepidozia cupressina (Sw.) Lindenb. & Lepidozia tenuicuspis Steph. & $A 8, A 9$ & $\begin{array}{l}\text { Allioni s.n. [Bryo. Levier 6559, } \\
\text { 6561] }\end{array}$ \\
\hline Lepidozia pseudocupressina Schiffn. & Lepidozia allionii Steph. & $\mathrm{A} 8, \mathrm{~A} 12$ & Allioni 507, 671, 713, 741 \\
\hline *Leptoscyphus amphibolius (Nees) Grolle & & 1 & Gradstein \& Pérez 11584 \\
\hline Leptoscyphus hexagonus (Nees) Grolle & Chiloscyphus purpureus Steph. & A15 & Allioni 704 \\
\hline *Leptoscyphus porphyrius (Nees) Grolle & & 1 & Gradstein \& Pérez 11591 \\
\hline Lophocolea bidentata (L.) Dumort. & & 4 & Gradstein \& Pérez 11575a, 11579 \\
\hline Lopholejeunea subfusca (Nees) Schiffn. & & 3 & Gradstein \& Pérez 11560 b p.p. \\
\hline Marchantia chenopoda L. & & $\mathrm{A} 0,1$ & $\begin{array}{l}\text { Allioni s.n. [Bryo. Levier 6408], } \\
\text { Gradstein \& Pérez s.n. }\end{array}$ \\
\hline *Marchesinia bongardiana (Lehm. \& Lindenb.) Trevis. & & 3 & Gradstein \& Pérez 11560 \\
\hline Marchesinia brachiata(Sw.) Schiffn. & & 1 & Gradstein \& Pérez 11606 \\
\hline Metzgeria allionii Steph. & & A5 & Allioni s.n. [Bryo. Levier 6396] \\
\hline
\end{tabular}




\begin{tabular}{|c|c|c|c|}
\hline Accepted name & Synonym(s) & Localities & Collections studied \\
\hline *Metzgeria crassipilis (Lindb.) A. Evans & & 2,4 & Gradstein \& Pérez 11557, 11566 \\
\hline Metzgeria leptoneura Spruce & $\begin{array}{l}\text { Metzgeria nudicosta Steph., } \\
\text { M. pilosa Steph. }\end{array}$ & $\mathrm{A} 8,1$ & $\begin{array}{l}\text { Allioni s.n. [Bryo. Levier 6398], } \\
\text { Gradstein \& Pérez 11599, } 11603\end{array}$ \\
\hline Microlejeunea epiphylla Bischler & & 2 & Gradstein \& Pérez 11555 p.p. \\
\hline *Mnioloma caespitosum(Spruce) R.M. Schust. & & & Gradstein \& Pérez 11608, 11609 \\
\hline *Monoclea gottschei Lindb. & & 1 & Gradstein \& Pérez 11589 \\
\hline $\begin{array}{l}\text { *Myriocoleopsis gymnocolea (Spruce) } \\
\text { M.E. Reiner \& Gradst. }\end{array}$ & & 1 & Gradstein \& Pérez 11576 \\
\hline Nardia succulenta (Lehm.) Spruce & Leioscyphus ecuadorensis Steph. & A14 & Allioni s.n. [Bryo. Levier 6508] \\
\hline Neesioscyphus allionii (Steph.) Grolle & Isotachis allionii Steph. & A6 & Allioni 226 \\
\hline *Nowellia curvifolia ((Dicks.) Mitt. & & 1 & Gradstein \& Pérez 11598 \\
\hline Odontolejeunea lunulata (F.Weber) Schiffn. & $\begin{array}{l}\text { Odontolejeunea ecuadorensis } \\
\text { Steph., O. nigrescens Steph., } \\
\text { O. spiniloba Steph. }\end{array}$ & $\mathrm{A} 1, \mathrm{~A} 14,1$ & $\begin{array}{l}\text { Allioni s.n. [Bryo. Levier 6549], } \\
11605 \text { p.p. }\end{array}$ \\
\hline Odontolejeunea rhomalea (Spruce) Steph. & $\begin{array}{l}\text { Odontolejeunea grandiloba } \\
\text { Steph. }\end{array}$ & $\mathrm{A0}, \mathrm{A} 15$ & Allioni s.n. \\
\hline *Odontoschisma variabile (Lindenb. \& Gottsche) Trevis. & & 1 & Gradstein \& Pérez 11586 \\
\hline $\begin{array}{l}\text { Otigoniolejeunea huctumalcensis } \\
\text { (Lindenb. \& Gottsche) Y.M. Wei et al. }\end{array}$ & $\begin{array}{l}\text { Ceratolejeunea dentatocornuta } \\
\text { Steph., Hygrolejeunea fissistipula } \\
\text { Steph. }\end{array}$ & A9, A13 & $\begin{array}{l}\text { Allioni 254, Allioni s.n. } \\
\text { [Bryo. Levier 5636] }\end{array}$ \\
\hline *Pallavicinia lyellii (Hook.) Carruth. & & 1 & Gradstein \& Pérez 11610 \\
\hline Plagiochasma rupestre (J.R. Forst. \& G. Forst.) Steph. & & $\mathrm{AO}$ & Allioni s.n. [Bryo. Levier 6601] \\
\hline Plagiochila adianthoides (Sw.) Lindenb. & $\begin{array}{l}\text { Plagiochila densispina Steph., } \\
\text { P. saladona Steph. }\end{array}$ & A7, A8 & Allioni s.n. [Bryo. Levier 6490] \\
\hline Plagiochila aerea Taylor & Plagiochila pungens Steph. & 1 & $\begin{array}{l}\text { Gradstein \& Pérez s.n. [collected } \\
\text { by Allioni in prov. Azuay] }\end{array}$ \\
\hline Plagiochila alternans Lindenb. \& Gottsche & Plagiochila rosariensis Steph. & A14 & $\begin{array}{l}\text { Allioni s.n. [Bryo. Levier 6367, } \\
6613 \text { ] }\end{array}$ \\
\hline Plagiochila cristata (Sw.) Lindenb. & Plagiochila allionii Steph. & A16 & Allioni 285 \\
\hline Plagiochila deflexa Mont. \& Gottsche & Plagiochila ecuadorensis Steph. & A14 & Allioni s.n. [Bryo. Levier 6363] \\
\hline Plagiochila deflexirama Taylor & Plagiochila bicaudata Steph. & $\mathrm{A} 0, \mathrm{A7}$ & $\begin{array}{l}\text { Allioni 215, s.n. [Bryo. Levier } \\
\text { 6389] }\end{array}$ \\
\hline *Plagiochila gymnocalycina (Lehm. \& Lindenb.) Mont. & & 1 & Gradstein \& Pérez 11585 \\
\hline Plagiochila heteromalla Lindenb. & Plagiochila paludosa Steph. & $\begin{array}{l}\text { A3, A8, } \\
\text { A9, A14 }\end{array}$ & $\begin{array}{l}\text { Allioni s.n. [Bryo. Levier 6358, } \\
6606,6618,6628 \text { ] }\end{array}$ \\
\hline Plagiochila macrostachya Lindenb. & Plagiochila sacramenti Steph. & A9, A13 & $\begin{array}{l}\text { Allioni 250, 253, 651, } \\
\text { Gradstein \& Pérez 11580, } 11607\end{array}$ \\
\hline Plagiochila montagnei Nees & Plagiochila nova Steph. & A15 & Allioni 709 \\
\hline Plagiochila raddiana Lindenb. & Plagiochila gualaquizana Steph. & $\begin{array}{l}A 1, A 2 \\
A 3, A 8,1 \\
2,3\end{array}$ & Gradstein \& Pérez 11555, 11582 \\
\hline Plagiochila rutilans Lindenb. & Plagiochila cobana Steph. & A14 & Allioni s.n. [Bryo. Levier 6490] \\
\hline *Plagiochila simplex (Sw.) Lindenb. & & 1 & Gradstein \& Pérez 11578 \\
\hline
\end{tabular}




\begin{tabular}{|c|c|c|c|}
\hline Accepted name & Synonym(s) & Localities & Collections studied \\
\hline Pycnolejeunea densistipula (Lehm. \& Lindenb.) Steph. & & A3 & Allioni s.n. [Bryo. Levier 6417] \\
\hline *Radula gottscheana Taylor & & 1 & Gradstein \& Pérez 11601 \\
\hline *Radula quadrata Gottsche & & 2 & Gradstein \& Pérez 11558 \\
\hline *Riccardia fucoidea (Sw.) Schiffn. & & 1 & Gradstein \& Pérez 11611, 11612 \\
\hline Riccardia leptophylla (Spruce) Herzog & Aneura allionii Steph. & A11 & Allioni s.n. [Bryo. Levier 6460] \\
\hline Riccardia regnellii (Ångstr.) K.G. Hell & & 1 & Gradstein \& Pérez 11597 \\
\hline *Riccia crassifrons Spruce & & 4 & Gradstein \& Pérez 11561 \\
\hline *Riccia fluitans L. & Riccia stenophylla Spruce & 4 & Gradstein \& Pérez 11563 \\
\hline${ }^{\star}$ Riccia vitalii Jov.-Ast & & 3 & Gradstein \& Pérez 11562 \\
\hline Scapania portoricensis Hampe \& Gottsche & Scapania minutidens Steph. & A16 & Allioni 291 \\
\hline *Solenostoma hyalinum (Hook.) Mitt. & & 1 & Gradstein \& Pérez 11583, 11593 \\
\hline *Symphyogyna brogniartii Mont. & & 1 & Gradstein \& Pérez 11613 p.p. \\
\hline *Syzygiella pectiniformis Spruce & & 1 & Gradstein \& Pérez 11592 \\
\hline Syzygiella sonderi (Gottsche) K. Feldberg et al. & Jamesoniella allionii Steph. & AO & Allioni s.n. [Bryo. Levier 6428] \\
\hline *Telaranea nematodes (Aust.) M. Howe & & 1 & Gradstein \& Pérez 11590 \\
\hline $\begin{array}{l}\text { *Thysananthus auriculatus (Wilson \& Hook.) } \\
\text { Sukkharak \& Gradst. }\end{array}$ & & 3 & Gradstein \& Pérez 11560 p.p. \\
\hline \multicolumn{4}{|l|}{ ANTHOCEROTOPHYTA } \\
\hline Dendroceros allionii Steph. & & A2 & Allioni 319 \\
\hline Dendroceros breutelii Nees & $\begin{array}{l}\text { Dendroceros ecuadorensis } \\
\text { Steph. }\end{array}$ & $A 1, A 4$ & $\begin{array}{l}\text { Allioni s.n. } \\
\text { [Bryo. Levier 6510, 6511] }\end{array}$ \\
\hline $\begin{array}{l}\text { Nothoceros vincentianus (Lehm. \& Lindenb.) } \\
\text { J.C. Villarreal }\end{array}$ & & 1 & Gradstein \& Pérez 11588 \\
\hline *Notothylas javanica (Sande Lac.) Gottsche & & 3 & Gradstein \& Pérez 11564 \\
\hline Phaeoceros carolinianus (Michx.) Prosk. & $\begin{array}{l}\text { Anthoceros allionii Steph., } \\
\text { A. gualaquizanus Steph. }\end{array}$ & $A 2, A 4$ & $\begin{array}{l}\text { Allioni 561, s.n. } \\
\text { [Bryo. Levier 6502] }\end{array}$ \\
\hline
\end{tabular}

